\title{
MARCELINE DESBORDES-VALMORE, Les Pleurs
}

\section{Lise Sabourin}

\section{(2) OpenEdition \\ Journals}

Édition électronique

URL : https://journals.openedition.org/studifrancesi/43989

DOI : 10.4000/studifrancesi.43989

ISSN : 2427-5856

\section{Éditeur}

Rosenberg \& Sellier

\section{Édition imprimée}

Date de publication : 1 juin 2021

Pagination : 224-225

ISSN : 0039-2944

\section{Référence électronique}

Lise Sabourin, « MARceline desbordes-valmore, Les Pleurs », Studi Francesi [En ligne], 193 (LXV | I) | 2021 mis en ligne le 01 juillet 2021, consulté le 15 octobre 2022. URL : http://journals.openedition.org/ studifrancesi/43989; DOI : https://doi.org/10.4000/studifrancesi.43989

Ce document a été généré automatiquement le 15 octobre 2022.

\section{(c) $(1) \odot$}

Creative Commons - Attribution - Pas d'Utilisation Commerciale - Pas de Modification 4.0 International - CC BY-NC-ND 4.0

https://creativecommons.org/licenses/by-nc-nd/4.0/ 


\title{
MARCELINE DESBORDES-VALMORE, LeS Pleurs
}

\author{
Lise Sabourin
}

\section{RÉFÉRENCE}

MARCELINE DESBORDES-VALMORE, Les Pleurs, présentation d'E. Pinon, Paris, GF, 2019, 303 pp.

1 Les poèmes de Marceline Desbordes-Valmore sont souvent évoqués, mais rarement accessibles aux lecteurs: c'est pourquoi cette édition en format de poche des Pleurs, présentée par Esther Pinon (pp.5-28), annotée et dotée d'un dossier (réception, parallèle d'autres voix féminines, aperçu sur la sociabilité romantique, chronologie, bibliographie, pp. 237-296), s'avère utile. Elle permet de lire vraiment cette œuvre minée par la déchirure d'une vie féconde en drames personnels.

2 Rien ne destinait cette provinciale née juste avant la Révolution à devenir une figure marquante du romantisme, mais les événements familiaux comme sociaux se chargent de changer sa destinée. La sérénité enfantine douaisienne est vite compromise par la séparation de ses parents, l'entraînant sur les planches lilloises puis dans les Antilles au fil des tribulations de la carrière maternelle. Le retour s'avère encore plus rude, par la précarité financière comme par la solitude affective et la mort de ses premiers nés. Son mariage avec Prosper Valmore, la naissance de trois enfants ne sont que des répits, tout comme son amour trahi pour Henri de Latouche.

3 Mais la souffrance engendre la poétesse, dès 1819 avec son premier recueil Élégies, Marie et Romances, puis en 1830 par ses Poésies, enfin avec ces Pleurs publiés chez Charpentier en 1833, avant une incursion dans le roman. Conjurer la douleur personnelle par l'échange avec la vie culturelle de son temps est une façon de voiler tout en révélant. Le papillon s'échappe du ver à soie en une transfiguration du réel digne de Louise Labé dont elle partage les élans passionnels tout en devant également les masquer. Mais le pittoresque s'invite aussi, dans la veine d'Aloysius Bertrand et de Thomas Moore, pour parler aux enfants qui sont sa consolation, hélas menacée par les deuils. Écriture 
chuchotée, versification souple, émotion retenue, transparence apparente caractérisent cette parole invaincue par sa fragilité assumée. 